\title{
ASSESSMENT OF WASH AND RESIDENTIAL CONDITIONS IN AJEROMI-IFELODUN AND LAGOS MAINLAND LOCAL GOVERNMENT AREAS
}

\author{
Isaiah Sewanu AKOTEYON * \\ Department of Geography and Planning, Lagos State University Ojo, PMB 0001 LASU Main Campus Post Office, \\ Badagry Expressway, Ojo Lagos, Nigeria, e-mail: sewanuakot@gmail.com \\ Ibrahim Rotimi ALIU \\ Department of Geography and Planning, Lagos State University Ojo, PMB 0001 LASU Main Campus Post Office, \\ Badagry Expressway, Ojo Lagos, Nigeria, e-mail: ibrahim.aliu@ lasu.edu.ng
}

Citation: Akoteyon, I. S., \& Aliu, I. R. (2020). Assessment of Wash and Residential Conditions in Ajeromi-Ifelodun and Lagos Mainland Local Government Areas. Analele Universităţii din Oradea, Seria Geografie, 30(1), 20-31. https://doi.org/10.30892/auog.301103-823

\begin{abstract}
The study assesses WASH and residential conditions in Ajeromi-Ifelodun and Lagos Mainland Local Government Areas of Lagos State. Three hundred questionnaires were administered to households in the study area using a systematic sampling technique. Both the descriptive and bivariate statistical techniques were employed for the data analysis. The result shows that the majority of the households are low-income earners with moderate household size within the 1-5 groups. The predominant bathroom facility is makeshift. More than three-quarter of the households have a waste bin in their dwelling. Open land waste disposal predominates in the study area. Significant dependence relationship exists between waste disposal method, and the LGAs obtained as $\chi^{2}=18.568 ; \mathrm{df}=4 ; \mathrm{p}<.001$. Approximately three-quarter of the dwellings are surrounded by stagnant water. The major source of water is borehole. About $74.0 \%$ and $72.7 \%$ of the respondents have access to improved sanitation and water respectively. Almost 50\% of the respondents lack sanitation facility within their dwelling. The study concluded that the dominance of stagnant water and open land disposal method poses serious environmental and human health challenges. The study recommends the enforcement of sanitary laws and developmental control and public enlightenment for sustainable socio-environmental and healthy residential.
\end{abstract}

Key words: access, hygiene, Lagos-Nigeria, residential condition, sanitation, water

$$
* \quad * \quad * * * *
$$

\section{INTRODUCTION}

Poor residential and sanitary conditions, the deplorable state of basic infrastructure characterized most of the informal settlements in developing countries (George, 1999). The paucity of the provision of decent housing, basic amenities, and poor sanitary conditions has contributed to 
the alarming rise in water-borne and vector-borne diseases in most parts of the developing cities. Water-borne and vector-borne diseases have social and economic effects which have been responsible for the current poverty level and underdevelopment in most developing countries. Poor residential conditions also have a serious implication on the economy and productivity of a nation's workforce (Olukolajo et al., 2013). The role of environmental sanitation is crucial in any human settlement because if properly handled, it will guarantee hygienic condition and promote public health, welfare, and quality of life in a sustainable manner (Ekong, 2015).

The importance of decent residential conditions is very vital for any society because it plays a major role in the health and well-being of an individual. One of the burning environmental issues confronting developing countries like Nigeria is deplorable housing and infrastructural challenges. The term, the environment can be broadly used to describe components such as water, air, soil and, the social and economic conditions (Ekong, 2015). The adverse effects of these environmental factors can result in serious health challenges in humans if not properly managed (Ekong, 2015). Most of the housing units lack adequate space, ventilation, waste collection, and disposal facility, sanitation, electricity, water supply, sanitation, and hygiene. According to Habib et al., (2009) decent housing remains one of the critical indicators of human health, comfort and well-being. A decent housing unit is expected to provide basic amenities such as adequate space, ventilation, waste collection, and disposal facility, sanitation, electricity, water supply and general environmental quality (Bashir, 2002; WHO, 2004; Udoh and Uyanga, 2013).

Housing standards vary from one country to another and also depend upon the climate, culture, level of urbanization, and the socio-economic condition (Adeoye, 2016). According to Onokerhoraye (1985), housing standards in Nigeria can be classified into two major categories namely; space standard, which deals with housing intensity development in relations to plot sizes, a number of buildings/ unit area of land and occupancy sizes. The second category deals with the performance standard, which emphasizes the quality of the environment. According to Ebong (1983) some criteria that can be employed in classifying housing quality include; aesthetics, ornamentation, sanitation, drainage, age of building, access to basic housing facilities, burglary, spatial adequacy, noise level within the neighborhood, sewage and waste disposal, air pollution and ease of movement among others. These broad classifications have been grouped into five based on certain basic criteria which any housing unit must possess. They are; lack of serious disrepair, energy-efficient, availability of modern facilities and services, healthy, safe and secure (Adeoye, 2016). These indicators comprised of variables such as; access to basic housing facilities, the quality of infrastructural amenities, spatial adequacy and quality of design, fixtures, and fittings, building layout and landscaping, noise and pollution control as well as security (Adeoye, 2016).

Literature abounds on sanitary and residential conditions studies. Majority of these studies focused on three major areas namely; the relationship between environmental quality of housing units and users' well-being, secondly, housing and its environment vis-a-vis user satisfaction and perception and thirdly, environmental quality as a factor in housing price structure (Morenikeji et al., 2017). Examples include housing and sales prices (Alkay, 2009), housing and inequality in socioeconomic characteristics (Wray et al., 2005, Owens, 2012), urban environmental quality and human well-being (Pacione, 2003) among others. Other scholars emphasized measures of housing quality and deterioration e.g. (Fiadzo, 1982; Bunch, 1996; Milroy et al., 2001; Khatun, 2009, Morenikeji et al., 2017). Most of these studies employed variables such as floors, wall and roofing materials, type of toilet facility, sources of water and lighting, drainage, street quality, proximity to other facilities and socio-economic variables such as education, income, religion, and race, etc.

Studies have shown that there exists a close relationship between human health and their residential conditions (Ineichen, 2003; Harker, 2006). According to FMH (2010), the health indicators for the citizens of Nigeria ranked among the worst in the world. Also, most of the vital health indicators in the country have either stagnated or worsened (WHO, 2005). A similar study by Asenso-Okyere (1994) in the Greater Accra region of Ghana showed that mosquitoes, 
dirty surroundings, unsafe water, poor air quality, and unhygienic conditions have a close link with poor housing condition.

Despite the vast research on residential conditions, there is a gap in knowledge in studies that incorporate the environmental aspect alongside housing quality in the study area. Hence, this study is aimed at assessing WASH and the residential conditions in Ajeromi-Ifelodun and Lagos Mainland Local Government Areas of Lagos state with a view to proffering policies that will guarantee the enforcement of sanitary laws and developmental control, upgrading of basic amenities and public enlightenment on the need for sustainable socio-environmental and healthy residential conditions of the populace were recommended.

\section{THE STUDY AREA}

The study area comprised of Ajeromi/Ifelodun, (AJIF) and Lagos Mainland (LML) Local Government Areas (LGAs) of Lagos state. The area is located between Longitude $3^{\circ} 20^{\prime} 0 \mathrm{E}$ and 3 ${ }^{\circ} 24^{\prime} 0$ ' $\mathrm{E}$ and on Latitudes $6^{\circ} 27^{\prime} 0{ }^{\prime} \mathrm{N}$ and $6^{\circ} 33^{\prime} 0 \mathrm{~N}$. The area is bounded on the East by Lagos Island and Lagos Lagoon, in the North by Shomolu, while Mushin and Surulere LGAs forms its western boundary. The southern part is flanked by Amuwo-Odofin and Apapa LGAs (figure 1).

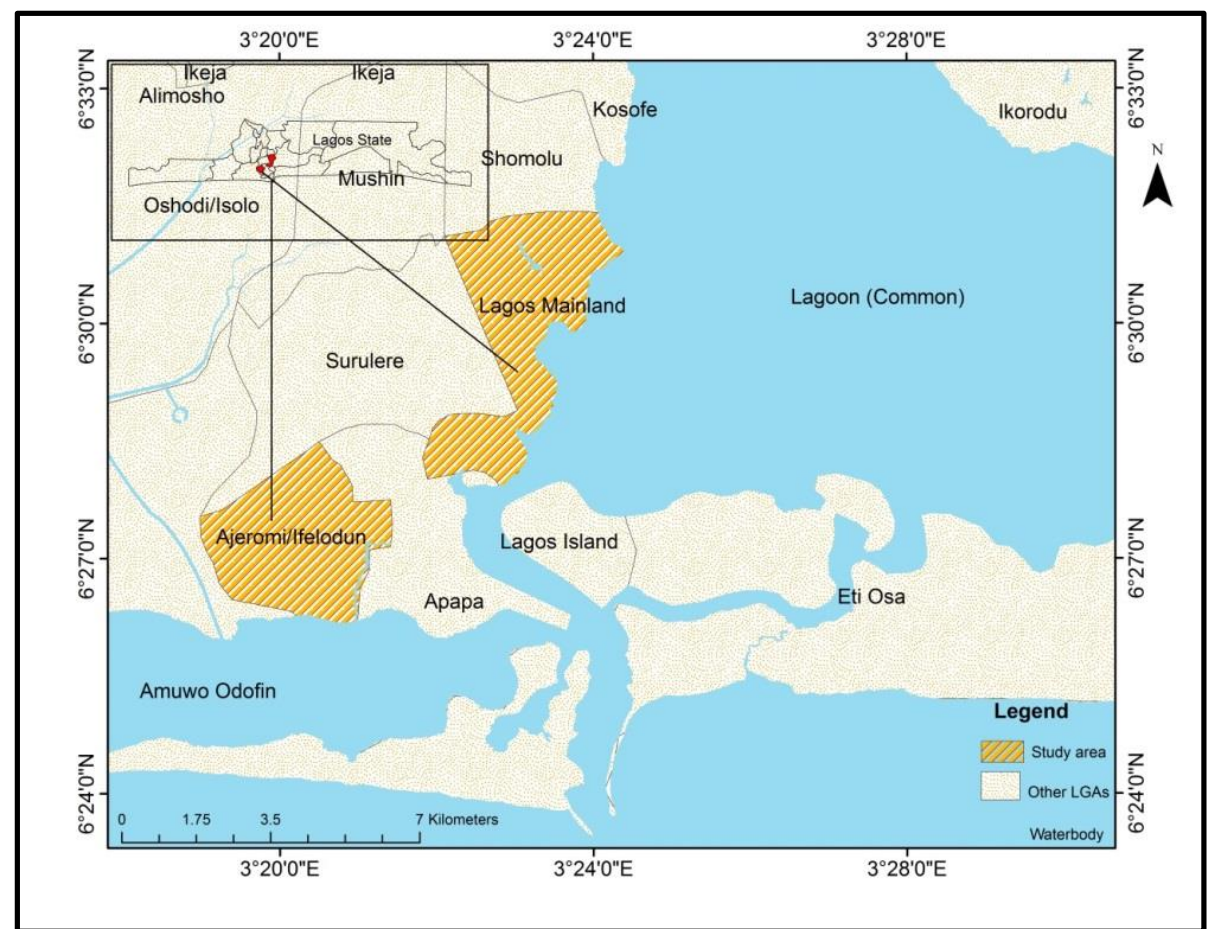

Figure 1. The study area

Source: Author's (2015)

The study area occupies about $87.0 \mathrm{~km}^{2}$ area of land while the population density (inch $/ \mathrm{km}^{2}$ ) is estimated to be about 71,796 . The climate is the tropical type with a mean daily temperature of about $30^{\circ} \mathrm{C}$ while the annual mean rainfall is about $1,532 \mathrm{~mm}$ (Odumosu et al., 1999). There are two major seasons namely; the dry season between November and March and the wet season spanning between April and October (Adetoyinbo \& Babatunde, 2010). The major vegetation consists of tropical swamp forest (freshwater/mangrove swamp forests and dry lowland rain forest). The drainage system consists of Lagoons occupying almost $22 \%$ of the state's total landmass. poses at the center, River Osun towards the east while it is drained by River Yewa in the 
west. The population is about 2,268,869 people (NPC, 2006). The major slum settlements in the study area include; Amukoko, Badia, Ilaje, Makoko, Oko-Agbon, and Iwaya. The settlements are characterized by poor water infrastructure, sanitation facilities, and poor drainage and road networks. There are no well-defined street layouts, the buildings are clustered with poor ventilation and lack of open space among others. The sources of water in the area comprised both improved and unimproved sources. The improved sources include; borehole, piped water connection, public standpipe, protected dug well and rainwater harvesting while the unimproved source consists of; unprotected dug well, Stream/River and vendor-provided water, sachet water, bottled water, etc. (UNICEF and WHO, 2014). In terms of sanitation facilities in the study area, two major types are recognized namely; improved sanitation e.g. connection to public sewer, connection to septic system, pour-flush latrine, simple pit latrine and ventilated improved pit latrine while the unimproved sources are; public or shared latrine, public or shared latrine and bucket latrine (UNICEF and WHO, 2014).

\section{MATERIALS AND METHODS}

A social survey was conducted through the administration of structured questionnaire directly at the household level during April to May 2015 covering Ajeromi-Ifelodun (AJIF) LGA and Lagos Mainland (LML) Local Government Areas of Lagos State. The survey aimed at assessing WASH and residential conditions in the study area. One hundred and fifty households each were interviewed in AJIF and LML LGAs totaling three hundred in the study area using a systematic sampling technique. The survey focused on four broad issues that are relevant to the aim of the study. They include; socio-economic, residential conditions, sanitary condition, and water, sanitation, and hygiene (WASH). A reliability test of the instrument used was employed using a standardized Cronbach's Alpha method (table 1).

Table 1. Reliability estimates of the instrument

Data source: Author's fieldwork (2015)

\begin{tabular}{|c|c|c|c|c|c|c|}
\hline Instrument & \multicolumn{5}{|c|}{ Scale Statistics } & $\begin{array}{c}\text { Reliability Statistics } \\
\text { (Cronbach's Alpha) }\end{array}$ \\
\hline Source & $\begin{array}{c}\text { No of } \\
\text { items }\end{array}$ & $\begin{array}{c}\text { No. of } \\
\text { Samples }\end{array}$ & Mean & SD & CV & $\mathrm{R}_{\mathrm{s}}$ \\
\hline $\begin{array}{c}\text { Socio-economic } \\
\text { status }\end{array}$ & 14 & 300 & 29.92 & 8.243 & 0.28 & 0.832 \\
\hline $\begin{array}{c}\text { Residential } \\
\text { conditions }\end{array}$ & $13(6)$ & 300 & 31.96 & 6.889 & 0.22 & 0.719 \\
\hline $\begin{array}{c}\text { Sanitation and } \\
\text { hygiene }\end{array}$ & 14 & 300 & 33.87 & 6.625 & 0.20 & 0.722 \\
\hline $\begin{array}{c}\text { Access to water } \\
\text { sources }\end{array}$ & 12 & 300 & 19.87 & 5.475 & 0.28 & 0.709 \\
\hline
\end{tabular}

KEY- SD- Standard Deviation, CV- Coefficient of Variation

The result of the reliability test of the sanitary and residential conditions in the study area indicates that the instruments are reliable, since the Cronbach's Alpha statistics obtained for each of the composite variables; $0.832(83.2 \%), 0.719(71.9 \%), 0.722(72.2 \%)$ and $0.709(70.9 \%)$ is > $70 \%$ threshold value. The results are supported by the coefficient of variation $(\mathrm{CV})$ values; 0.28 , $0.22,0.20$ and 0.28 which are respectively less than 0.50 threshold value, indicating homogeneity on how the respondents rated the items. Hence, there is an internal consistency of the responses from the respondents and therefore the data do not violate the assumption of reliability. The benchmark according to UNICEF and WHO (2014) was adopted for the definitions of improved water source and improved sanitation. 
Data collected from the field were inputted into the IBM statistical package for social sciences (SPSS) version 22 for analysis. Frequency and percentages, chi-square, independent samples T-Test were employed for the data analysis. Chi-square was employed to establish the interdependence of the variables while the independent samples T-Test was employed to determine whether there is a significant difference between the two study areas. The results were presented in tables and charts using Excel 2003 software while ArcMap 10.3 was used to generate the map of the study area.

\section{RESULTS AND DISCUSSION}

\section{Socio-demographic characteristics of households}

The result of the socio-demographic characteristics of the respondents is presented in table 2. The result shows that gender distribution indicates that approximately $50 \%$ each of the respondents were either male or female. On the marital status, $56.3 \%$ of the households were married. The age distribution of respondents interviewed indicated that the majority representing $32.3 \%$ were above 35 years. The educational attainment reveals that majority of the households $58.3 \%$ were secondary school certificate holders. The occupational distribution showed that traders were the majority representing 51.3 percent. The dominant ethnic group is the Yoruba tribe with $62.3 \%$. The household's members were largely low-income earners with about $30.7 \%$ within 20,000 to 24,000 income group. The household size is relatively moderate with the majority within the 1-5 groups.

Table 2. Socio-demographic characteristics of households Data source: Author's fieldwork (2015)

\begin{tabular}{|c|c|c|c|}
\hline Variables & Options & Frequency & Percentage \\
\hline \multirow[t]{2}{*}{ Sex } & female & 148 & 49.3 \\
\hline & male & 152 & 50.7 \\
\hline \multirow[t]{4}{*}{ Marital status } & widow & 8 & 2.7 \\
\hline & single & 121 & 40.3 \\
\hline & married & 169 & 56.3 \\
\hline & divorced & 2 & 0.7 \\
\hline \multirow[t]{4}{*}{ Age } & $20-25$ years & 63 & 21.0 \\
\hline & $26-30$ years & 64 & 21.3 \\
\hline & $31-35$ years & 76 & 25.3 \\
\hline & $>35$ years & 97 & 32.3 \\
\hline \multirow[t]{4}{*}{ Education } & no formal education & 53 & 17.7 \\
\hline & primary & 27 & 9.0 \\
\hline & secondary & 175 & 58.3 \\
\hline & tertiary & 45 & 15.0 \\
\hline \multirow[t]{5}{*}{ Occupation } & Unemployed & 54 & 18.0 \\
\hline & farming & 3 & 1.0 \\
\hline & artesian & 81 & 27.0 \\
\hline & civil servant & 8 & 2.7 \\
\hline & traders & 154 & 51.3 \\
\hline \multirow[t]{5}{*}{ Ethnic group } & Foreigners & 37 & 12.3 \\
\hline & Yoruba & 187 & 62.3 \\
\hline & Hausa & 12 & 4.0 \\
\hline & Igbo & 64 & 21.3 \\
\hline & no response & 2 & 0.7 \\
\hline \multirow[t]{4}{*}{ Household size } & $1-5$ & 247 & 82.3 \\
\hline & $6-10$ & 42 & 14.0 \\
\hline & $11-15$ & 5 & 1.7 \\
\hline & above 15 & 4 & 1.3 \\
\hline \multirow[t]{5}{*}{ Income } & $<10,000$ & 64 & 21.3 \\
\hline & $10,000-14000$ & 35 & 11.7 \\
\hline & $15,000-19,000$ & 70 & 23.3 \\
\hline & $20,000-24,000$ & 92 & 30.7 \\
\hline & $>25,000$ & 39 & 13.0 \\
\hline
\end{tabular}


The result of the economic status of the household shows that a greater percentage own a colored television set with $77.3 \%$ and $64.7 \%$ representing AJIF and LML LGAs respectively (table 3). More than three-quarter of the households do not subscribe to any form of newspaper in the study area (see table 3). The predominant regular mode of transportation in the study area is public transport with approximately $94.75 \%$ and $91.3 \%$ from LML and AJIF LGAs respectively. The majority use a personal phone for their regular communication (table 3).

Table 3. Economic status of household in the study area

Data source: Author's fieldwork (2015)

\begin{tabular}{|c|c|c|c|c|}
\hline Variable & LGA & Option & Frequency & Percentage \\
\hline \multirow[t]{6}{*}{ Television type } & AJIF & none & 29 & 19.3 \\
\hline & & black and white & 5 & 3.3 \\
\hline & & colored & 116 & 77.3 \\
\hline & LML & none & 49 & 32.7 \\
\hline & & black and white & 4 & 2.7 \\
\hline & & colored & 97 & 64.7 \\
\hline \multirow[t]{8}{*}{ No newspapers subscription } & AJIF & none & 118 & 78.7 \\
\hline & & one & 27 & 18.0 \\
\hline & & two & 3 & 2.0 \\
\hline & & three & 2 & 1.3 \\
\hline & LML & none & 123 & 82.0 \\
\hline & & one & 25 & 16.7 \\
\hline & & two & 2 & 1.3 \\
\hline & & three & 2 & 1.3 \\
\hline \multirow[t]{6}{*}{ Mode of regular transportation } & AJIF & foot/bicycle & 1 & .7 \\
\hline & & public transport & 137 & 91.3 \\
\hline & & personal car/ taxi & 12 & 8.0 \\
\hline & LML & foot/bicycle & 2 & 1.3 \\
\hline & & public transport & 142 & 94.7 \\
\hline & & personal car/ taxi & 6 & 4.0 \\
\hline \multirow{8}{*}{$\begin{array}{l}\text { Mode of regular } \\
\text { communication }\end{array}$} & AJIF & friend/ families & 9 & 6.0 \\
\hline & & postage & 3 & 2.0 \\
\hline & & public phone booth & 2 & 1.3 \\
\hline & & personal phone & 136 & 90.7 \\
\hline & LML & friend/ families & 5 & 3.3 \\
\hline & & postage & 4 & 2.7 \\
\hline & & public phone booth & 1 & .7 \\
\hline & & personal phone & 140 & 93.3 \\
\hline
\end{tabular}

\section{Residential conditions in the study area}

The housing status, type, and age of the building are presented in figure 2 . The result shows that the majority are tenants with almost $90.0 \%$ and $65.3 \%$ residential in a rented apartment in LML and AJIF LGAs respectively. The implication of this is the majority will settle for cheap accommodation with which often lack basic amenities. A study conducted by Oni and Durodola (2010), in the urban core of Akure, revealed that low-income earners have a peculiar taste for tenement properties because of its low rent. Their findings corroborate the result of this study because the majority of the households are low-income earners and consequently tenants. Single room predominates in AJIF while room and parlor is the dominant dwelling type in LML. The majority of the buildings were constructed more than 9 years ago. This has implication for habitability because is a strong correlation between habitability of housing and their age. This has been reported by Omole (2010) in his study at Akure. He argued that buildings erected in more recent times tend to be more habitable compared to the earlier ones because it has direct effects on the state of health, socio-economic well-being and emotional stability of the residents. 


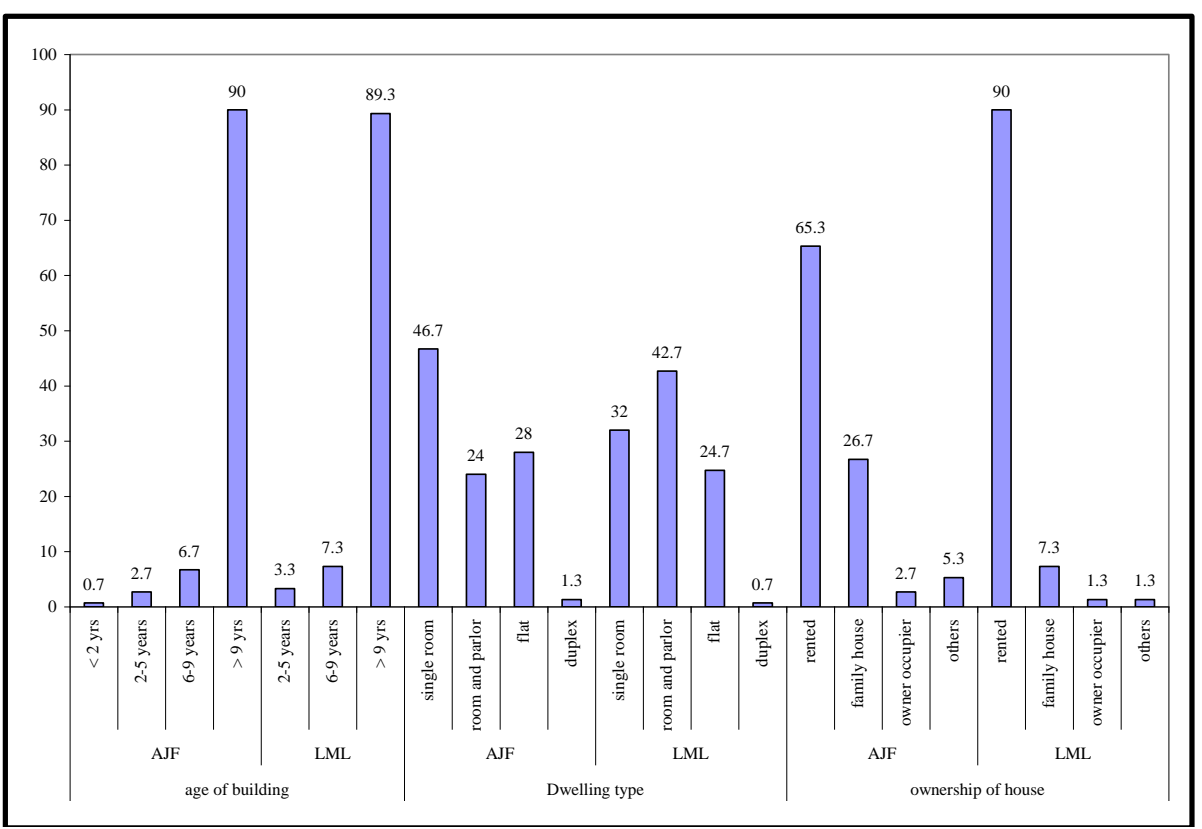

Figure 2. Housing status, type, and age of the building Source: Author's (2015)

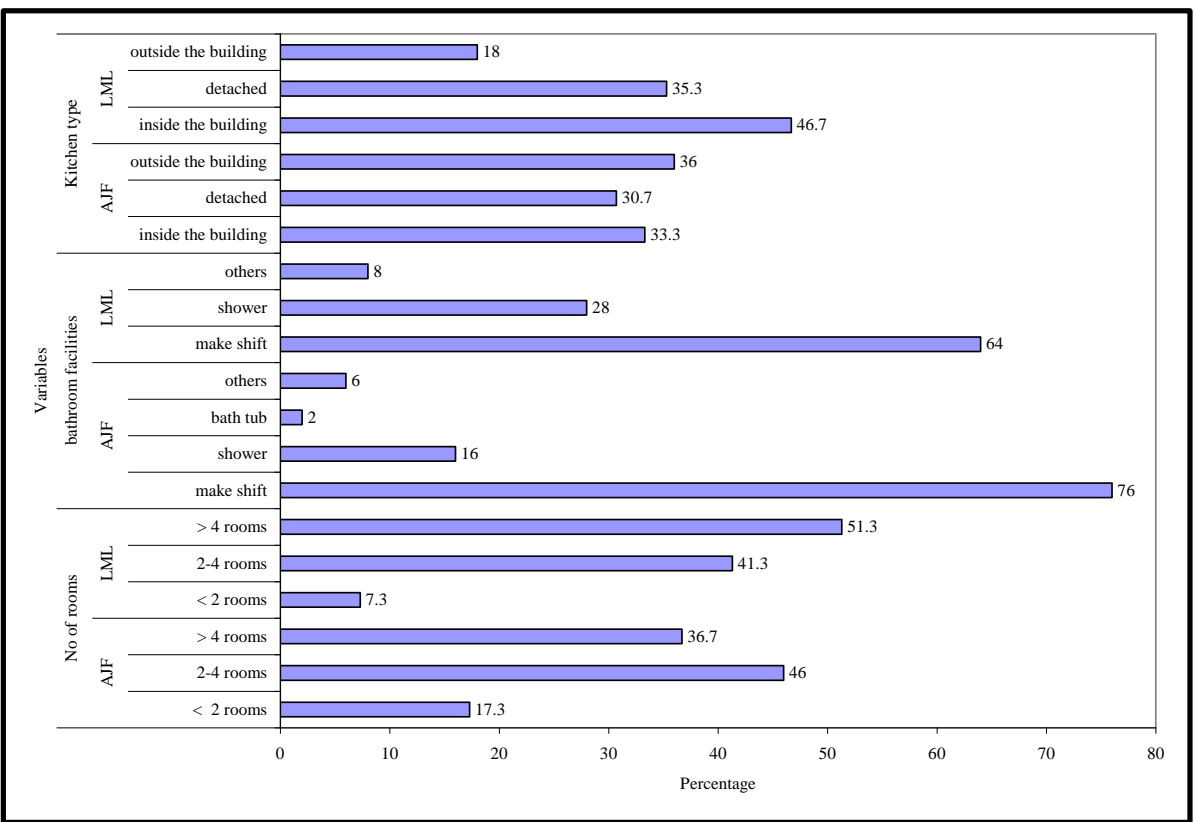

Figure 3. Housing facilities

Source: Author's (2015)

Figure 3 presents the housing facilities in the study area. The results show that the buildings in LML were designed for four rooms and above while those in AJIF ranged from 2 to 4 rooms. The majority of the households use the makeshift bathroom with about $76 \%$ and $64 \%$ representing 
AJIF and LML LGAs respectively (see figure 3). Households in AJIF have their kitchens outside the building whereas, in LML, the kitchens are constructed inside the building.

\section{Sanitary conditions in the study area}

The sanitary condition in the study area indicates that more than three-quarter of the households have a waste bin in their dwelling for waste collection (figure 4). The predominant waste disposal method in the area is open land with approximately $96.7 \%$ and $82 \%$ of the households from LML and AJIF LGAs respectively. Significant dependence relationship exists between waste disposal method and the LGAs obtained as $\chi^{2}=18.568$; $\mathrm{df}=4 ; \mathrm{p}<.001$. The occurrence of solid waste pile around dwelling is more predominant in AJIF LGA compared to LML. More than three-quarter of the dwellings are surrounded by stagnant water (see figure 4). The entire study area is devoid of the waste network.

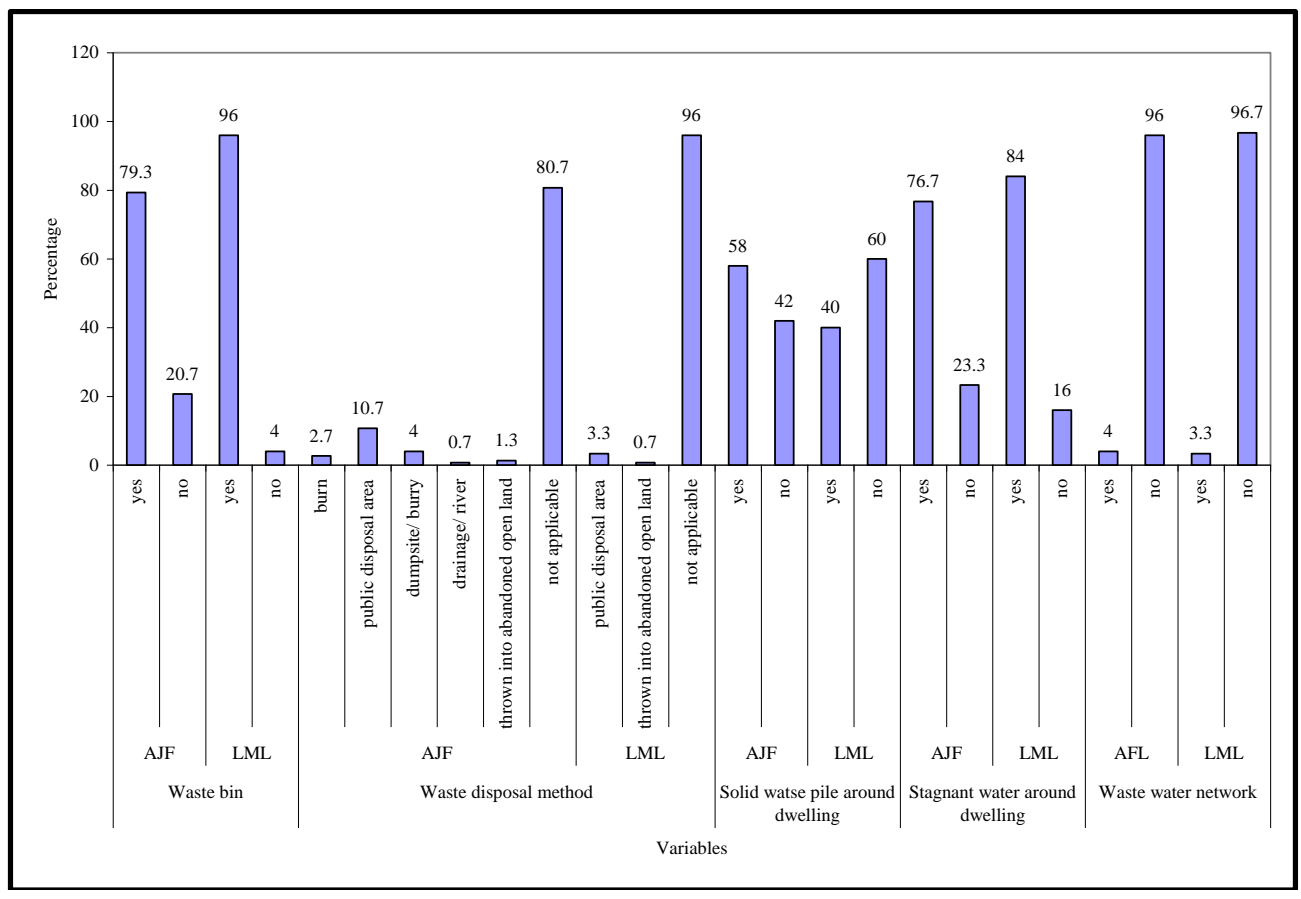

Figure 4. Sanitary condition in the study area

Source: Author's (2015)

The result of the descriptive statistics of the independent samples T-test is presented in table 4. The result indicates that the response score on economic status is obtained as 3.04 for AJIF and 3.01 for LML. The mean response score on housing quality is obtained as 8.91 and 8.79 respectively for AJIF and LML. The mean response score on households' sanitation and sanitary conditions is obtained as 9.65 and 9.70 respectively for AJIF and LML, while the mean response score on households' access to water sources is obtained as 1.71 and 1.80 respectively for AJIF and LML. The independent samples T-test for significant difference between the two study areas on the composite variable show that there is no significant difference between AJIF and LML based on households' socio-economic status, residential conditions of the residents, sanitation and sanitary conditions, and households access to water sources given as $\mathrm{t}=0.215,1.162,-0.515$ and -1.752 (since $\mathrm{p}=0.830,0.246,0.607$ and 0.081 $>0.05$ significance level) respectively (table 5). The result implied that the residential condition of residents in the two LGAs is the same. 
Table 4. Descriptive statistics of independent samples T-test of the variables Data source: Author's fieldwork (2015)

\begin{tabular}{|c|c|c|c|c|c|}
\hline Variables & LGAs & $\mathrm{N}$ & Mean & $\begin{array}{c}\text { Std. } \\
\text { Deviation }\end{array}$ & $\begin{array}{c}\text { Std. Error } \\
\text { Mean }\end{array}$ \\
\hline \multirow{2}{*}{ Socio-economic status } & AJIF & 150 & 3.0400 & 1.44650 & .11811 \\
\cline { 2 - 6 } & LML & 150 & 3.0067 & 1.23428 & .10078 \\
\hline \multirow{2}{*}{ Residential conditions of residents } & AJIF & 150 & 8.9133 & .94788 & .07739 \\
\cline { 2 - 6 } & LML & 150 & 8.7933 & .83784 & .06841 \\
\hline \multirow{2}{*}{ Households sanitation and sanitary condition } & AJIF & 150 & 9.6533 & .82728 & .06755 \\
\cline { 2 - 6 } & LML & 150 & 9.7000 & .73958 & .06039 \\
\hline \multirow{2}{*}{ Households access to water } & AJIF & 150 & 1.7133 & .45372 & .03705 \\
\cline { 2 - 6 } & LML & 150 & 1.8000 & .40134 & .03277 \\
\hline
\end{tabular}

Table 5. Independent Samples T-test of the variables Data source: Author's fieldwork (2015)

\begin{tabular}{|c|c|c|c|c|c|c|c|}
\hline \multirow{2}{*}{$\begin{array}{c}\text { Variable } \\
\text { Equal variances } \\
\text { assumed) }\end{array}$} & $\mathrm{t}$ & $\mathrm{df}$ & $\mathrm{Sig}$. & $\begin{array}{c}\text { Mean } \\
\text { Difference }\end{array}$ & $\begin{array}{c}\text { Std. Error } \\
\text { Difference }\end{array}$ & $\begin{array}{c}\text { 95\% Confidence } \\
\text { Interval of the } \\
\text { Difference }\end{array}$ \\
\cline { 2 - 8 } & & & & & & Lower & Upper \\
\hline Socio-economic status & 0.215 & 298 & .830 & .03333 & .15526 & -.27221 & .33888 \\
\hline $\begin{array}{c}\text { Residential conditions of } \\
\text { residents }\end{array}$ & 1.162 & 298 & .246 & .12000 & .10329 & -.08328 & .32328 \\
\hline $\begin{array}{c}\text { Households sanitation and } \\
\text { sanitary conditions }\end{array}$ & -0.515 & 298 & .607 & -.04667 & .09060 & -.22497 & .13164 \\
\hline $\begin{array}{c}\text { Households access to } \\
\text { water }\end{array}$ & -1.752 & 298 & .081 & -.08667 & .04946 & -.18400 & .01067 \\
\hline
\end{tabular}

\section{ACCESS TO WATER AND SANITATION IN THE STUDY AREA}

\section{Sources of water supply and access to improved water in the study area}

The major source of water in the study area is borehole representing 50.3\% and a marginal $25 \%$ for vendor-provided water while rainwater accounted for the least. Based on access to the improved source, $72.7 \%$ of the respondents have access to improved water in the study area (figure 5). The disparity over the LGAs shows that $87.3 \%$ and $58 \%$ have access to improved source in LML and AJIF LGAs respectively. The chi-square test indicates that there is significant dependence between the sources of water and the LGAs obtained as $\chi^{2}=88.504$, df $=8, \mathrm{p}<.000$. Regarding safe water source (piped public tap, public standpipe, borehole connection and protected dug well connection), about $62.3 \%$ of the respondents have access to a safe water supply. The variations over LGAs show that $84 \%$ and $40.7 \%$ of the respondents have access to safe water supply in LML and AJIF LGAs respectively (figure 5).

\section{Types of sanitation facilities and access to improved sanitation in the study area}

The available sanitation facilities in the study area show that half of the respondents interviewed do not have any form of sanitation facility within their dwelling. Connection to septic system predominates with $15.8 \%$ followed by pour-flush latrine $(13.8 \%)$. The least sanitation facility is open-pit latrine with $0.8 \%$. Access to sanitation in the study area shows that $74.0 \%$ of the respondents have access to sanitation facilities (figure 6). Across the LGAs, CSS, and PSL predominate in LML representing $44.7 \%$ and $32.7 \%$ respectively. The dominant toilet faculties in AJIF are PFL and SPL (figure 6). 


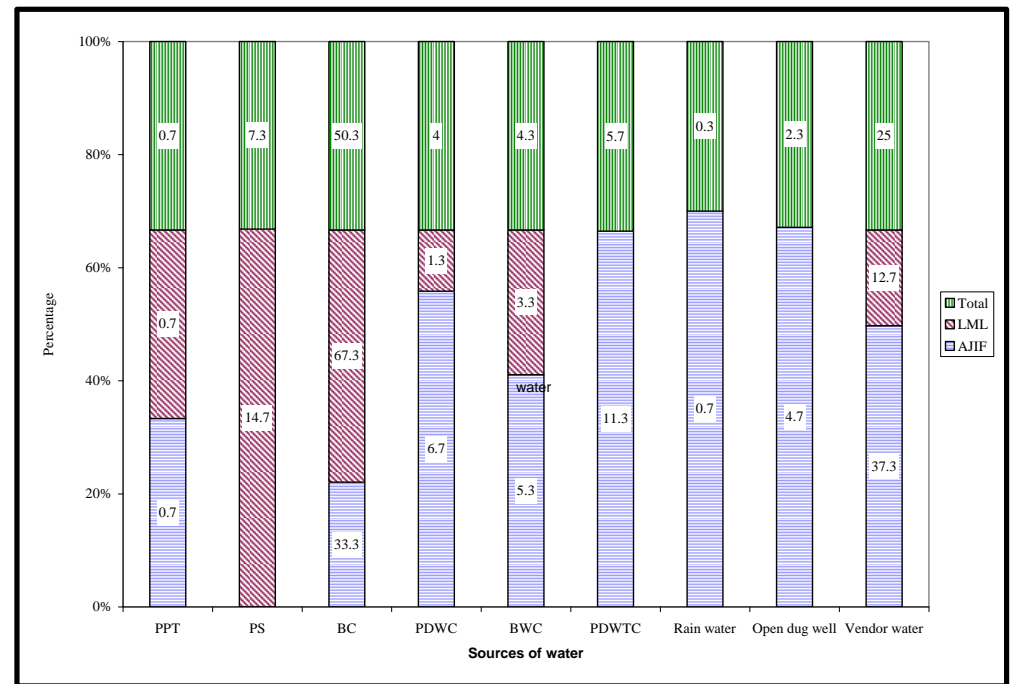

Figure 5. Access to water supply in the study area Source: Author's (2015)

KEY- PPT- piped public tap, PS- public standpipe, BC- borehole connection, PDWC- protected dug well connection, BWC- borehole without connection, PDWTC- protected dug well without connection

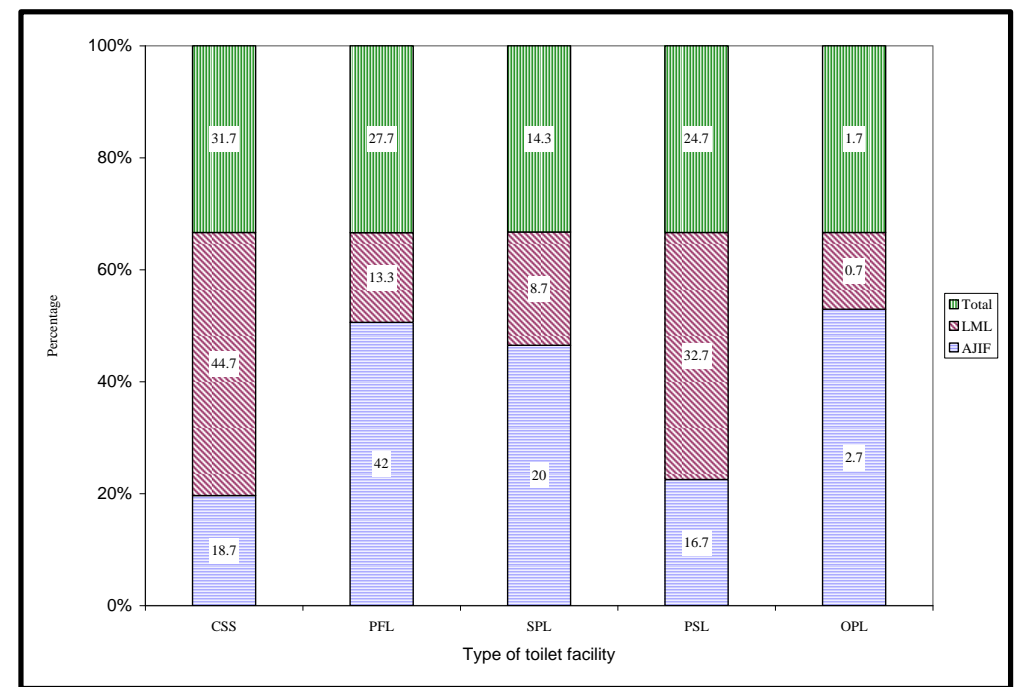

Figure 6. Access to sanitation facility in the study area Source: Author's (2015)

KEY- CSS- connection to septic system, PFL- pour-flush latrine, SPL- simple pit latrine, PSL- public or shared latrine, OPL- open pit latrine

\section{CONCLUSION}

The result of the socio-demographic characteristics shows that the household's members were largely low-income earners while the household size is relatively moderate with the majority within the 1-5 groups. The majority of the respondents are tenants. The dominant dwelling type is single room/room and parlor in AJIF and LML respectively. Most of the buildings in the study area are relatively old based on their age. Makeshift bathroom predominates in the study area while households from AJIF and LML have their kitchens constructed outside and inside the building respectively. 
More than three-quarter of the households have a waste bin in their dwelling for waste collection and the dominant waste disposal method is open land. Significant dependence relationship was established between the waste disposal method and the LGAs. The occurrence of solid waste pile around dwelling is more predominant in AJIF while approximately three-quarter of the dwellings have stagnant water around their dwellings. The independent samples T-test between the two study areas on the composite variable shows that there is no significant difference between AJIF and LML based on households' socio-economic status, residential conditions, sanitation, and sanitary conditions, and access to water.

The major source of water in the study area is borehole while rainwater is the least source. More than three-quarter of the respondents have access to improved water in the study area. The chi-square test indicates that there is significant dependence between the sources of water and the LGAs. Safe water provision in the study area revealed that more than half of the respondents have access. About half of the respondents interviewed do not have any form of sanitation facility within their dwelling. More than three-quarter of the respondents have access to sanitation in the study area. The study concluded that the dominance of stagnant water and open land disposal method poses a serious threat to the environment and human health. Additionally, the nonavailability of sanitation facility within the household has an implication on hygiene. Policies that will guarantee the enforcement of sanitary laws and developmental control, upgrading of basic amenities and public enlightenment on the need for sustainable socio-environmental and healthy residential conditions of the populace were recommended.

\section{REFERENCES}

Adeoye, D. O. (2016). Challenges of urban housing quality: Insights and experiences of Akure, Nigeria', Procedia-Social and Behavioral Sciences, 216, 260-268.

Adetoyinbo, A., \& Babatunde, A. (2010). Quality of hand-dug wells in selected locations in Lagos Coastal Aquifer, Nigeria. Report and Opinion, 2 (3), 51-54.

Alkay, E. (2009).The relationship between environmental quality level and housing sale prices in the Istanbul Metropolitan Area', A Z ITU Journal of the Faculty of Architecture, 6(1), 60-76.

Asenso-Okyere, K. (1994).Socio-economic factors in malaria control.World Health Forum, 15(3), 265-268.

Bashir, S. A. (2002). Home is where the harm is: inadequate housing as a public health crisis. American Journal of Public Health, 92 (5), 733-738.

Bunch, M. J. (1996). Physical Ecology of Slums in Madras. Indian Geographical Journal, 71 (1),12-32.

Ebong, M. O. (1983). The perception of residential quality: a case study of Calabar, Nigeria.Third World Planning Review, 5(3), 273-284.

Ekong, I. E. (2015). An assessment of environmental sanitation in an urban community in Southern Nigeria', African Journal of Environmental Science and Technology, 9(7), 592-599.

Federal Ministry of Health (FMH) Nigeria. (2010). National Strategic Health Development Plan' (2010-2015).

Fiadzo, E. (1982). On the estimation of determinants of housing quality: the case of Ghana. Joint Centre for Housing Studies, Harvard University.

George, C. K. (1999). Basic Principles and Methods of Urban and Regional Planning, Lagos. Nigeria: Libra-Gen Limited.

Habib, R. R., Mahfoud, Z., Fawaz, M., Basma, S. H. \& Yeretzian, J. S. (2009). Housing quality and ill health in a disadvantaged urban community. Public Health, 123 (2), 174-181.

Harker, L. (2006). Chances of a lifetime: the impact of bad housing on children's lives, Shelter, London.

Ineichen, B. (2003). Homes and Health: How housing and health interact. Routledge.

Khatun, T. (2009). Measuring environmental degradation by using principal component Analysis. Environment, Development and Sustainability, 11 (2), 439-457.

Milroy, C. A., Borja, P. C., Barros, F. R. \& Barreto, M. L. (2001). Evaluating sanitary quality and classifying urban sectors according to environmental conditions. Environment and Urbanization, 13 (1), 235-255.

Morenikeji, W., Umaru, E., Pai, H., Jiya, S., Idowu, O. \& Adeleye, B. M. (2017). Spatial analysis of housing quality in Nigeria. International Journal of Sustainable Built Environment, 6 (2), 309-316.

National Population Census (NPC) (2006). Details of the breakdown of the national and state provisional population totals', Official Gazette, 96 (2), 1-42, the Federal Republic of Nigeria, Abuja.

Odumosu, T. (1999). Location and regional setting of Lagos State', in Balogun, Y., Odumosu, T and Ojo, K. (Eds.): Lagos State in Maps, pp.1-3, Rex Charles Publication, Ibadan. 
Olukolajo, M. A., Adewusi, A. O., \& Ogungbenro, M. T. (2013). Influence of Housing Condition on the Health Status of Residents of Urban Core of Akure, Nigeria'. International Journal of Development and Sustainability, 2 (2), 1567 1579.

Omole, K. F. (2010). An assessment of housing condition and socio-economic lifestyles of slum dwellers in Akure, Nigeria. Contemporary Management Research, 6(4),73-290.

Oni, A. O. \& Durodola, D. O. (2010). Disputes resolution amongst residents of Tenement properties in Lagos, Nigeria'. Global Jour. of Engg. \& Tech, 3(4), 661-670.

Onokerhoraye, A. G. (1985). Benin: a traditional African city in transition. Benin Social Science Series for Africa.

Owens, A. (2012). Neighborhoods on the rise: A typology of neighborhoods experiencing socioeconomic ascent. City and Community, 11(4), 345-369.

Pacione, M. (2003). Urban environmental quality and human well-being — a social geographical Perspective. Landscape and Urban Planning, 65(1-2),19-30.

Udoh, U.\& Uyanga, J. (2013). Housing conditions and health in rural Nigeria: A study of Akwa Ibom State. Res Humanit Soc Sci, 3(8), 34-41.

WHO (2004). Reviews of Evidence in History and Health: Background Department. Budapest Fourth Ministerial Conference on Environment and Health.

WHO (2005). WHO Country Cooperation Strategy (CCS). Federal Republic of Nigeria 2002-2007. WHO Regional Office for Africa Brazzaville

UNICEF \& WHO (2014). Targets and Indicators Post-2015: Recommendations from International Consultations. Comprehensive Recommendations-Updated April 2014.

Wray, R., Emo, M., Birch, S., Hutchison, B., Eyles, J. \& Abernathy, T. (2005) Inequalities in neighborhood socioeconomic characteristics: potential evidence-base for neighborhood health planning. International Journal of Health Geographics, 4 (1), 20.

Submitted:

June 12, 2019
Revised:

December 26, 2019
Accepted and published online

February 11, 2020 